\title{
Prevalence of Microsporidiosis in Different Hosts in Turkey: A Meta-analysis
}

\section{Türkiye'de Farklı Konaklarda Microsporidiosis Prevalanst: Bir Meta-analiz}

\author{
(1) Ülfet Çetinkaya ${ }^{1}$, (1) Armağan Caner $^{2}$ \\ ${ }^{1}$ Erciyes University, Halil Bayraktar Health Vocational High School, Kayseri, Turkey \\ ${ }^{2}$ Erciyes University Faculty of Medicine, Department of Biophysics, Kayseri, Turkey
}

Cite this article as: : Çetinkaya Ü, Caner A. Prevalence of Microsporidiosis in Different Hosts in Turkey: A Meta-analysis. Turkiye Parazitol Derg 2020;44(4):232-8.

\begin{abstract}
Objective: Microsporidia are opportunistic obligate intracellular pathogens which infect many vertebrate and invertebrate hosts. This study aimed at investigating all evidence about microsporidia infection in human and other vertebrate hosts in Turkey. Methods: This study covered all prevalence studies, related to microsporidiosis in Turkey until April 2020, that were found in Web of Science, PubMed, Scopus, and ULAKBIM databases were considered in this meta-analysis. A total of 168 studies were identified in the systematic literature research. After the initial assessment, only 15 articles (12 humans and three other vertebrates) were included for meta-analysis. Data analysis was carried out using the Revman 5.3 (Review Manage 5.3) software.

Results: With the evaluation of these studies, it was found that the prevalence of microsporidia in humans ( $\mathrm{n}=6.707$ ) and other vertebrate hosts $(\mathrm{n}=506)$ was $13.4 \%$ and $15.2 \%$, respectively. The risk ratio in the patient groups was 2.87 compared to the control group [95\% confidence interval (CI): 1.20-6.87, $\mathrm{I}^{2}=87 \%, \mathrm{p}<0.00001$ ]. There was no difference between genders and parasite prevalence (95\% CI: $\left.1.00-1.39, \mathrm{I}^{2}=18 \%, \mathrm{p}=0.29\right)$. The prevalence of microsporidia was also found to be high in patients with diarrhea (95\% CI: 1.09-1.58, $\mathrm{I}^{2}=86 \%, \mathrm{p}=0.0001$ ) and in immunosuppressed individuals (95\% CI: $1.86-3.70, \mathrm{I}^{2}=16 \%, \mathrm{p}=0.31$ ). Conclusion: Although there are few studies on the prevalence of these parasites, the results of this meta-analysis provides extensive information about the current situation in Turkey.
\end{abstract}

Keywords: Microsporidia, Turkey, prevalence, meta-analysis

öz

Amaç: Microsporidia türleri, omurgalı ve omurgasız konakçıların çoğunu enfekte eden, zorunlu hücre içi fırsatçı patojenlerdir. Bu çalışmada, Türkiye'de insan ve diğer omurgalı konaklardan bildirilen microsporidia enfeksiyonlarıyla ilgili tüm kanıtların incelenmesi ve değerlendirilmesi amaçlanmıştır.

Yöntemler: Bu meta-analizde, Web of Science, PubMed, Scopus ve ULAKBIM veri tabanlarında, Nisan 2020'ye kadar Türkiye'de microsporidiosis prevalansı ile ilgili yapılmış çalışmalar dikkate alınmıştır. Sistematik literatür araştırmasında 168 çalışma tespit edilmiştir. İlk değerlendirmenin ardından sadece 15 makale (12'si insan ve 3'ü diğer omurgalılar) meta-analize dahil edilmiştir. Verilerin analizinde Revman 5.3 (Review Manage 5.3) yazılımı kullanılmıştır.

Bulgular: Bu çalışmaların değerlendirilmesi ile insanlarda $(n=6,707)$ ve diğer omurgalı konaklarda $(n=506)$ microsporidia prevalansının sırasıyla \%13,4 ve \%15,2 olduğu görülmüştür. Hasta grubu/kontrol grubu risk oranı 2,87 idi [\%95 güven aralığ1 (GA): 1,20-6,87, $\left.\mathrm{I}^{2}=\% 87, \mathrm{p}<0,00001\right]$. Cinsiyetler ve parazit prevalans1 arasında istatistiksel anlamlı fark yoktu (\%95 GA: 1,001,39, $\left.\mathrm{I}^{2}=\% 18, \mathrm{p}=0,29\right)$. İshali olan hastalarda (\%95 GA: 1,09-1,58, $\left.\mathrm{I}^{2}=\% 86, \mathrm{p}=0,0001\right)$ ve bağışıklığ baskılanmış bireylerde (\%95 GA: 1,86-3,70, I²=\%16, p=0,31) microsporidia prevalansının yüksek olduğu görüldü.

Sonuç: Bu parazitlerin prevalansı hakkında çok az çalışma olmasına rağmen, bu meta-analiz Türkiye'deki mevcut durum hakkında genel bir bilgi vermektedir.

Anahtar Kelimeler: Microsporidia, Türkiye, prevalans, meta-analiz

Received/Geliş Tarihi: 28.07.2020 Accepted/Kabul Tarihi: 18.09.2020

Address for Correspondence/Yazar Adresi: Ülfet Çetinkaya, Erciyes University, Halil Bayraktar Health Vocational High School, Kayseri, Turkey

Phone/Tel: +90 3522076666 E-mail/E-Posta: ucetinkaya@erciyes.edu.tr ORCID ID: orcid.org/0000-0001-5527-3741 


\section{INTRODUCTION}

Microsporidia are obligate intracellular pathogens infecting eukaryotic cells of many vertebrates and invertebrates $(1,2)$. More than 1.200 species have been reported in 144 genera and 14 out of these species in seven genera have been identified as human pathogens. Enterocytozoon bieneusi and Encephalitozoon intestinalis are the most common species and are often associated with infections of the gastrointestinal tract. Encephalitozoon species are not limited to intestinal system enterocytes, but they also parasitize in other organs and tissues such as nervous system and respiratory system, causing different clinical situations $(1,2)$. Although microsporidia species generally cause self-limiting diarrhea in immunocompetent individuals, it is a serious cause of morbidity and mortality in immunocompromised patients. While the number of microsporidiosis cases was quite limited due to the insufficient interest in this issue before the AIDS pandemic, the role of microsporidia species in human pathology has become well known since the outbreak of AIDS and they are considered to be opportunistic pathogens that cause life-threatening infections in many immune-compromised diseases $(3,4)$. Besides humans, microsporidia are known as pathogens of various animals such as fishes, fur-bearing animals, pets, honey bees, silkworms and grasshoppers. Especially, E. bieneusi infections are reported from primates, cats, cattle, dogs, horses, pigs, birds and various wild mammals from various parts of the world emphasizing that they are potential reservoirs for human infections (5-7).

In our country, the number of studies on the frequency of microsporidian pathogens in humans or other vertebrates is very limited. In this study, it was aimed to determine the prevalence of microsporidiosis in humans and other vertebrate hosts through a systematic review and meta-analysis in Turkey, and attract attention to this situation. In addition, the relationship of microsporidia prevalence with gender and various clinical conditions was tried to be revealed.

\section{METHODS}

The current study was conducted according to the Meta-analysis of observational studies in epidemiology (PRISMA) guidelines (8).

\section{Search Method}

Web of Science, PubMed, Scopus, and ULAKBIM databases were used for searching articles. Articles in both English and Turkish language have been included in this study. After the search of the above databases, manual searches were conducted. All published articles until April 2020 were chosen. Keywords used for searches are as following: Microsporidium, Microsporidiosis, Microsporidia, Encephalitozoon, E. bieneusi, Prevalence, Epidemiology, Turkey.

\section{Inclusion and Exclusion Criteria}

All studies were included in this review by the following criteria: 1-All chosen articles should be published before April 2020; 2-The studies reporting the prevalence of microsporidiosis in any age group in Turkey; 3-The studies in humans and other vertebrate; 4-Original research articles; 5-Full text studies.

Studies were excluded from the review by the following criteria: 1-The review articles; 2 -The studies in invertebrates; 3 -The articles that used other diagnostic methods, except staining, molecular techniques and IFA-Mabs; 4-The articles written in another language than English and Turkish; 5-The studies without raw data; 6-The studies with sample size less than 20.
The suitability of all studies was considered by two different authors. After selecting articles, the authors recorded the following information in a standard data extraction form. A flow diagram of the study design process is shown in Figure 1.

\section{Data Extraction}

After the searches were completed, each study was transferred to the pre-designed excel form as main titles. Information recorded was first author's name, publication year, gender, host, patient group, total participants, type of sample, positive cases, diagnostic methods, genus or species of the organism and type of study. Two different groups were established from the studies with control group to investigate the relationship between immune status/ diarrhea and microsporidiosis.

\section{Statistical Analysis}

Random effects model and fixed effect model were used in meta-analysis of the data. However, the results of the random effects model were taken as basis in the interpretation. In the random effects model, the Mantel-Haenszel method was applied to estimate the variance (tau-square) among the studies. 95\% confidence interval (CI) was chosen. Heterogeneity among the studies was evaluated with $\mathrm{I}^{2}$ values. $\mathrm{I}^{2}$ value that is above $50 \%$ was evaluated as high heterogeneity and p-value $<0.05$ was interpreted as meaning heterogeneity was significant.

\section{RESULTS}

\section{Selection of Studies}

The systematic literature search resulted in with 168 studies. After removing duplicates, 62 studies remained. 47 studies were
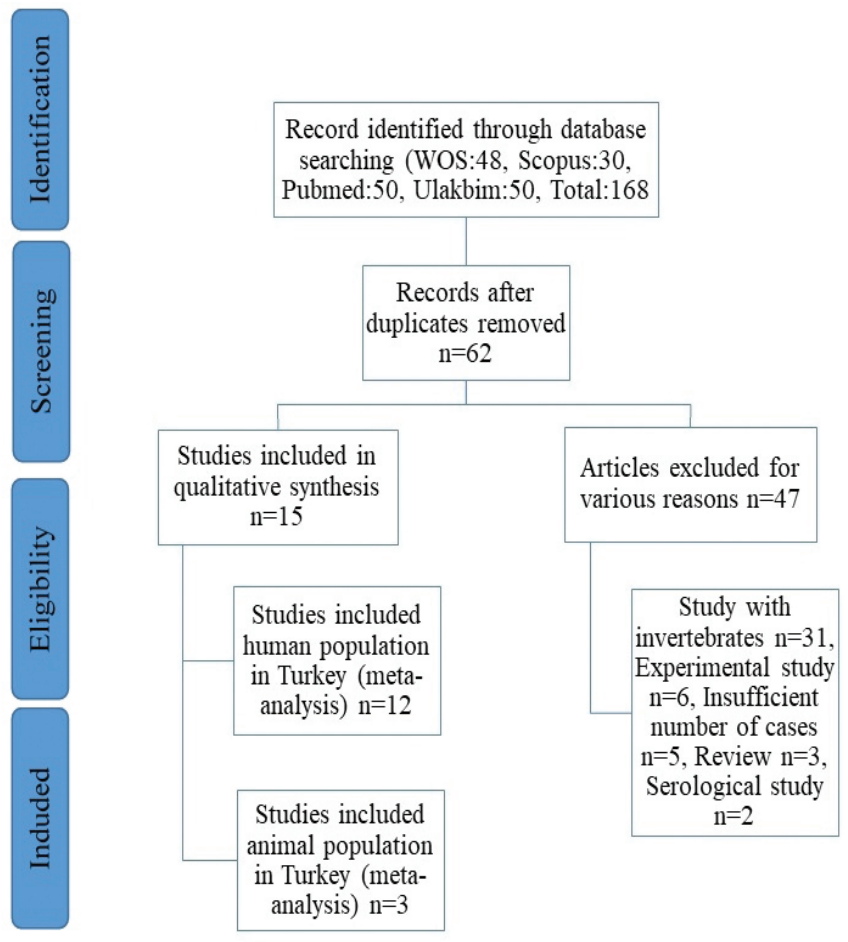

Figure 1. Flow diagram of the search and selection of studies on the prevalence of microsporidiosis in Turkey 
excluded for various reason (Thirty-one studies were performed on invertebrate hosts; six studies were experimental; the number of cases in five studies was insufficient; three studies were review articles; different methods were used in two studies). Only 15 articles were included for entry in the meta-analysis (Figure 1).

\section{Prevalence of Microsporidia in Human and Other Vertebrates}

Prevalence information of human microsporidiosis ( $\mathrm{n}=6.707$ ) in Turkey are reported in 12 studies (Table 1). Overall prevalence of human microsporidiosis was $13.4 \%$ (9-20).

Five studies without control group were excluded from the analysis. Seven studies with control group were evaluated as patient and control group. For the prevalence of microsporidia infection in the patient group, due to the heterogeneity of the studies, metaanalysis calculations were performed with selecting random effect model. The risk rate of microsporidia in the total patient group is 2.87 and $95 \%$ CI 1.20 , 6.87. Considering the meta-analysis data of the patient group, heterogeneity between studies was $\mathrm{I}^{2}=87 \%(\mathrm{p}<0.00001)$ and statistically significant. There is a statistically significant difference in microsporidia positivity between the control group and the patient group (Figure 2). In other vertebrate hosts, three publications investigating the prevalence of microsporidia $(n=504)$ were found (Table 2). Forest graphics were not drawn because these studies are not controlled. Highest prevalence was found in cattle (19.3\%) followed by cat $(14.5 \%)$ and dog (9.7\%). Overall prevalence of microsporidiosis for all animal species was $15.2 \%$ (21-23).

\section{Microsporidiosis in Humans Based on Subgroups}

Prevalence of microsporidiosis in humans according to different genders, stool appearance and immune status is summarized in Table 3.

Ineightstudiesreportinggendersandmicrosporidiosis positivity, the number of infected individuals has been found over thousands (Female $n=1.141$, Male $\mathrm{n}=1.219$ ). For the prevalence of microsporidiosis by gender, meta-analysis calculations were performed by selecting random effect model according to the heterogeneity of the studies. According to the meta-analysis evaluation, there was no statistically significant difference $(\mathrm{p}=0.06)$ between genders. Among studies, heterogeneity is $\mathrm{I}^{2}=18 \%$ and is not statistically significant $(\mathrm{p}<0.29)$ (Figure $3 \mathrm{~A}$ ).

Six studies evaluating the relationship between diarrhea and microsporidiosis were found ( $\mathrm{n}=1.118)$. Only four of these studies had control group ( $n=756$ ) and only these studies were included for further analyses. The prevalence of microsporidia was $41.9 \%$ in patients with diarrhea and $32.1 \%$ in those without diarrhea. The incidence of microsporidia

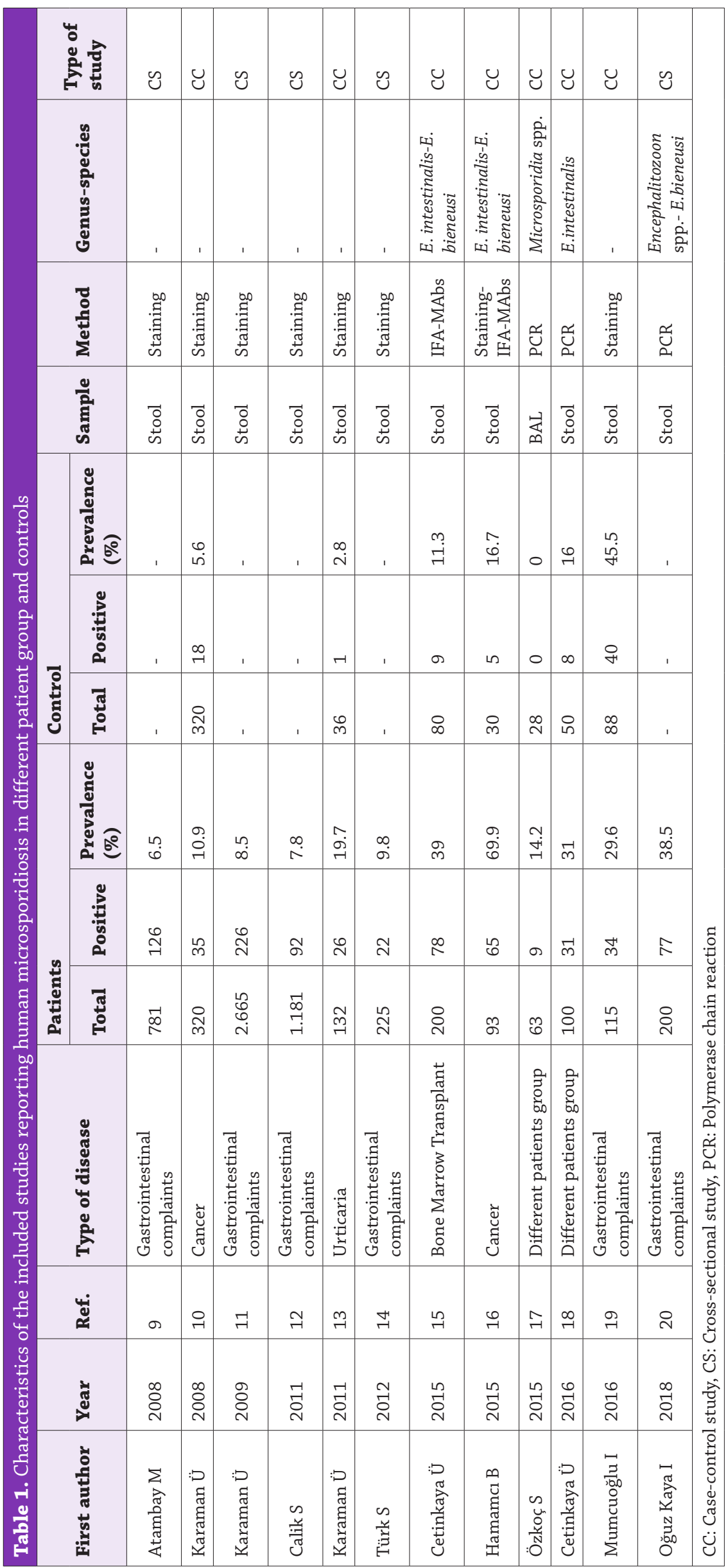


Table 2. Characteristics of the included studies reporting microsporidiosis in other vertebrate hosts

\begin{tabular}{|l|l|l|l|l|l|l|l|l|l|}
\hline First author & Year & Ref. & Host & Total & Positive & Prevalence (\%) & Sample & Method & Genus-species \\
\hline Duzlu O & 2019 & 21 & Dog & 282 & 41 & 14.5 & Stool & PCR & E. intestinalis- E. hellem \\
\hline Pekmezci D & 2019 & 22 & $\begin{array}{l}\text { Domestic } \\
\text { Cat }\end{array}$ & 72 & 7 & 9.7 & Stool & PCR & $\begin{array}{l}\text { Encephalitozoon spp.- E. } \\
\text { bieneusi }\end{array}$ \\
\hline Bilgin T & 2020 & 23 & Cattle & 150 & 29 & 19.3 & Stool & PCR & E. bieneusi \\
\hline \multicolumn{9}{|l|}{ PCR: Polymerase chain reaction } \\
\hline
\end{tabular}

Table 3. Prevalence of microsporidiosis in humans according to different gender, stool appearance and immune status

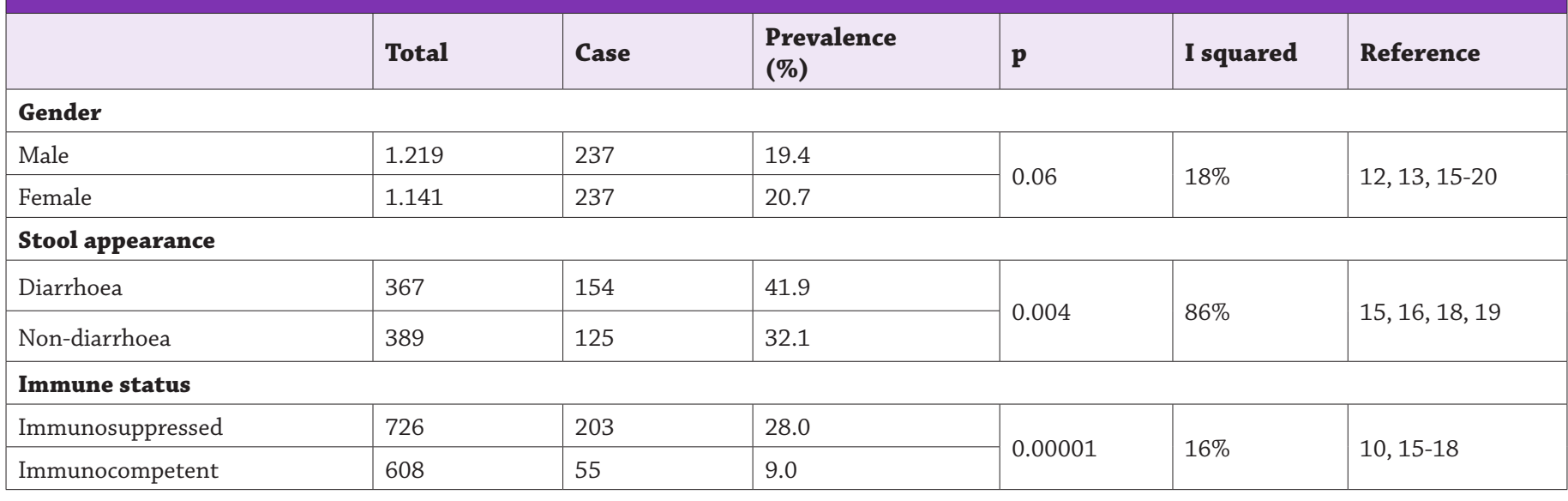

\begin{tabular}{|c|c|c|c|c|c|}
\hline \multirow[b]{2}{*}{ Study or Subgroup } & \multicolumn{2}{|c|}{ Patient Group } & \multicolumn{2}{|c|}{ Control Group } & \multirow[b]{2}{*}{ Weight } \\
\hline & Events & Total & Events & Total & \\
\hline Cetinkaya 2015 & 78 & 200 & 9 & 80 & $18.2 \%$ \\
\hline Cetinkaya 2016 & 38 & 125 & 1 & 25 & $10.1 \%$ \\
\hline Hamamcı 2015 & 65 & 93 & 5 & 30 & $17.1 \%$ \\
\hline Karaman 2008 & 35 & 320 & 18 & 320 & $18.6 \%$ \\
\hline Karaman 2011 & 26 & 132 & 1 & 36 & $10.0 \%$ \\
\hline Mumcuoglu 2016 & 34 & 115 & 40 & 88 & $19.4 \%$ \\
\hline Ozkoc 2016 & 9 & 63 & 0 & 28 & $6.5 \%$ \\
\hline Total $(95 \% \mathrm{Cl})$ & & 1048 & & 607 & $100.0 \%$ \\
\hline Total events & 285 & & 74 & & \\
\hline
\end{tabular}

Risk Ratio

M-H, Random, $95 \%$ Cl

$3.47[1.83,6.57]$

$7.60[1.09,52.81]$

$4.19[1.86,9.44]$

$1.94[1.13,3.36]$

$7.09[1.00,50.49]$

$0.65[0.45,0.94]$

$8.61[0.52,142.97]$

$2.87[1.20,6.87]$

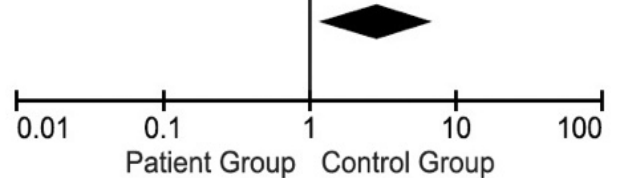

Figure 2. Forest plot diagram showing microsporidiosis in human $\mathrm{CI}$ : Confidence interval between two groups is statistically significant $(\mathrm{p}=0.004)$. The risk ratio of microsporidia was 1.31 in those with diarrhea [95\% CI $(1.09,1.58)]$. Heterogeneity $\left(\mathrm{I}^{2}=86 \%\right)$ was found to be high and statistically significant among patients with diarrhea $(\mathrm{p}<0.00001)$ (Figure 3B).

Eight studies evaluating the relationship between immune status and microsporidiosis were found $(n=3.499)$. Only five of these studies had control group $(n=1.334)$ and only these studies were included for further analyses. The prevalence of microsporidia was $28 \%$ in immunocompromised patients and $9 \%$ in immunocompetent patients. The incidence of microsporidia between two groups is statistically significant $(\mathrm{p}<0.00001)$. The risk ratio of microsporidia was 2.62 in those with immunocompromised patients [95\% CI (1.86, 3.70)].
Heterogeneity is $\mathrm{I}^{2}=16 \%$. It was found to be high and is not statistically significant ( $\mathrm{p}=0.31$ ) (Figure $3 C$ ).

\section{Discussion}

This systematic review by meta-analysis provides a comprehensive overview of the prevalence of microsporidiosis in both humans and other vertebrates from 2008 to the present day. The data were analyzed by considering healthy individuals and patient groups such as, patients with and without diarrhea symptoms, the immune status of the patients as well as a gender of patients. This study was conducted using 15 articles found in the four databases and documenting the prevalence of microsporidiosis in Turkey until April 2020. 


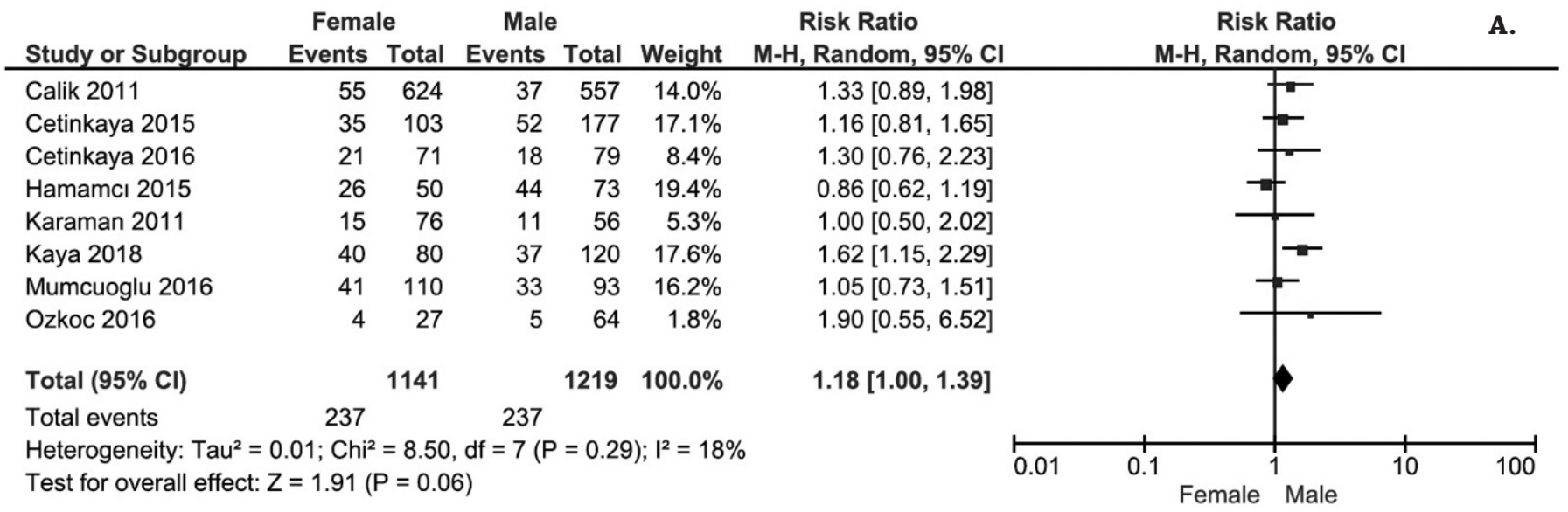

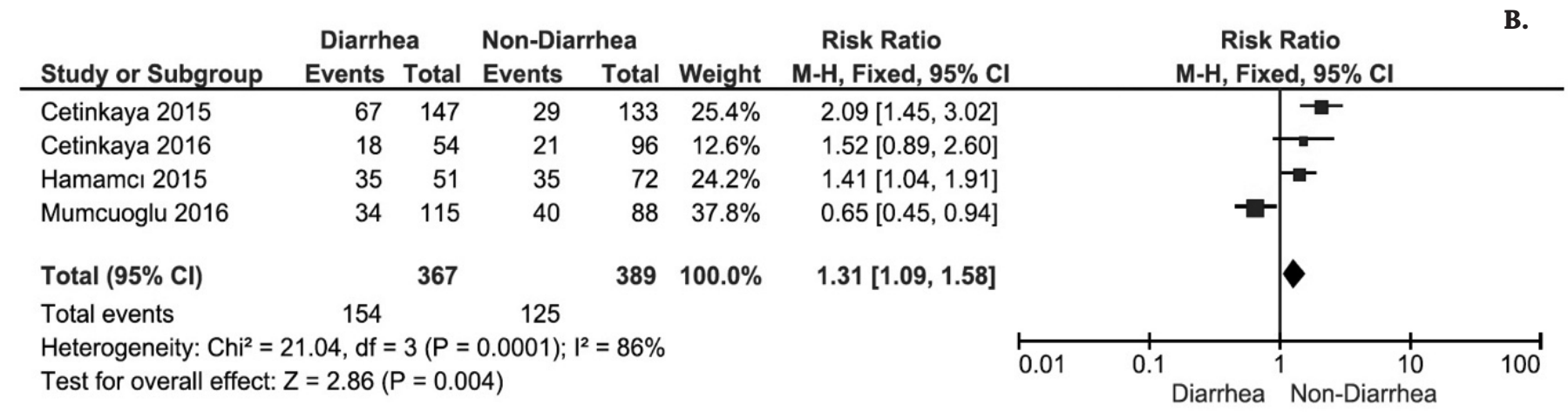

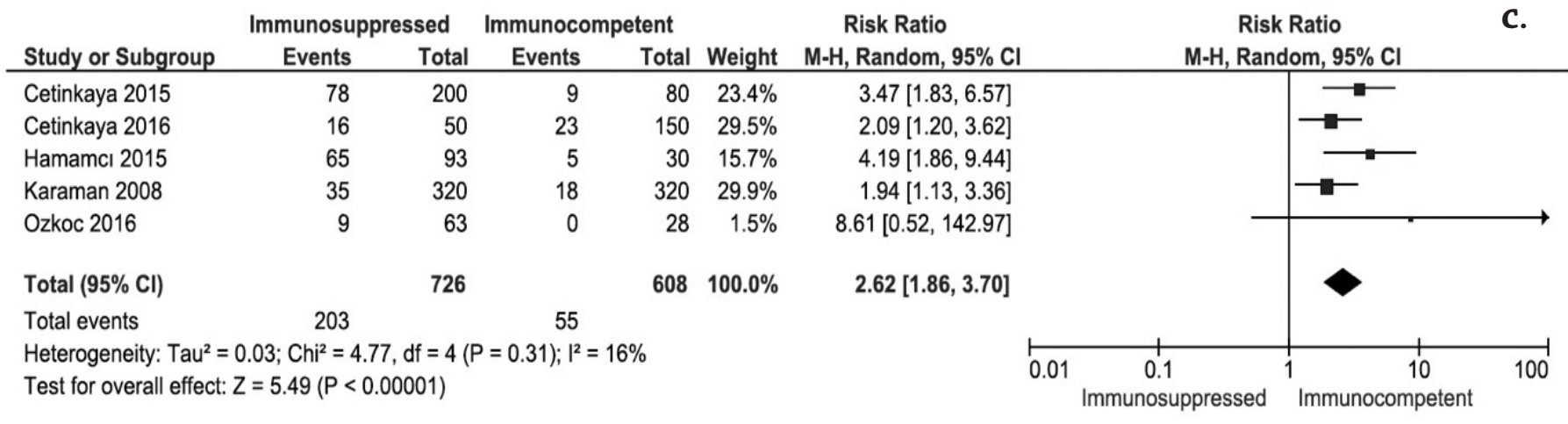

Figure 3. Forest plot diagram showing prevalence of microsporidiosis in different genders (A), patients with diarrhea (B) and according to immune status of individuals (C)

CI: Confidence interval

The highest prevalence reported in humans is in patients diagnosed with cancer (69.9\%) (16). The highest prevalence reported in other vertebrate hosts is in healthy-looking cattle (19.3\%) (21). This large difference is thought to be due to the all prevalence studies in humans are conducted on patients with clinical complaints or immunosuppressed individuals, while in other vertebrates studies were mainly investigating this parasite in healthy-looking animals. However, when all the cases in the articles were evaluated, it was found that there was a lower prevalence in humans (13.4\%) than other vertebrates (15.2\%). It was observed that this situation is similar to that of the Chinese population (24). Studies on human microsporidiosis have also been reported that $E$. intestinalis is the dominant species and other species are reported to be a lesser abundant $(15,16,20)$. These findings are similar to the findings of the study on dogs (21), that suggesting zoonotic transmission. In similar studies, some animal species have been reported to be infected by microsporidian species that commonly found in humans and are considered as reservoirs for human infections $(25,26)$.

In our study, microsporidia were observed at a higher rate in female than male, but this difference between gender was not statistically significant. On the other hand, in meta-analysis studies conducted in Iran (27) and in China (24), it was reported that the parasite was more common in male, although it was also not statistically significant. Another subgroup evaluated in terms of microsporidia prevalence in our study was the presence of 
diarrhea in patients. In this study, microsporidia prevalence was found higher in patients with diarrhea and this difference was statistically significant. These findings are similar to the study conducted on the Iranian (27) and Chinese population (24).

The microsporidia are opportunistic pathogens. The immune system of the persons plays a key role in the severity and course of the disease (1,2). Microsporidia prevalence in immunocompromised patients is $28 \%$ in Turkey (Table 3 ). This is a very high rate compared to the control group and statistically significant. This rate is highest in patients with cancer (Table 1). These findings are similar to the study conducted on the Iranian (27) and Chinese population (24). The prevalence of this pathogen has been studied in different patients such as cancer or organ transplant $(10,15,16,18)$, but there is no study conducted in HIV-positive individuals in our country, while these studies are concentrated on AIDS patients worldwide. This is a big gap that needs to be filled.

To our knowledge, this study is the first systematic review and meta-analysis of microsporidiosis prevalence in Turkey. However, this meta-analysis has some limitations that can affect the results. The first of these is being made only on people in four cities. There are still regions with no data. Secondly, there are only three studies on other vertebrate hosts and all these studies are on different species of animals. In these studies, it should be expanded both in different provinces and in different hosts. Thirdly, the methods used in diagnosis are very different from each other. In addition, the number of studies performed for species distinction and molecular characterization is very low. Especially, the phylogenetic analysis of the species detected in humans is not well studied and the inadequacy in studies on vertebrate hosts constitute a large gap in terms of zoonotic transition and reservoir hosts. As a result, we think that increasing the use of molecular methods in diagnosis and performing more detailed studies on different hosts will be beneficial for our knowledge about the transmission of these parasites and risk factors.

\section{* Ethics}

Ethics Committee Approval: Ethics committee approval was not because it is a meta-analysis study.

Informed Consent: No patients were used in the study. It is a meta-analysis study.

Peer-review: Externally and internally peer-reviewed.

\section{* Authorship Contributions}

Surgical and Medical Practices: Ü.Ç., Concept: Ü.Ç., Design: Ü.Ç., Data Collection or Processing: Ü.Ç., Analysis or Interpretation: A.C., Literature Search: Ü.Ç., Writing: Ü.Ç.

Conflict of Interest: The authors confirm that this article content has no conflict of interest.

Financial Disclosure: The authors declared that this study received no financial support.

\section{REFERENCES}

1. Didier ES, Weiss LM. 2006. Microsporidiosis: current status. Curr Opin Infect Dis 2006; 19: 485-92.

2. Franzen $C$, Müller A. Microsporidiosis: human diseases and diagnosis. Microbes Infect 2001; 3: 389-400.
3. Lobo ML, Xiao L, Antunes F, Matos O. Microsporidia as emerging pathogens and the implication for public health: a 10-year study on HIVpositive and -negative patients. Int J Parasitol 2012; 42: 197-205.

4. Sak B, Kváč M, Kučerová $Z$, Květoňová $D$, Saková K. Latent microsporidial infection in immunocompetent individuals a longitudinal study. PLoS Negl Trop Dis 2011; 5: e1162.

5. Santin M, Fayer R. Microsporidiosis: enterocytozoon bieneusi in domesticated and wild animals. Res Vet Sci 2011; 90: 363-71.

6. Thellier M, Breton J. Enterocytozoon bieneusi in human and animals, focus on laboratory identification and molecular epidemiology. Parasite 2008; 15: 349-58.

7. Canning EU. Microsporidia. In: Kreier JP, Baker JR, editors. Parasitic protozoa. Massachusetts: Academic Press; 1993.p.299-385.

8. Moher D, Shamseer L, Clarke M, Ghersi D, Liberati A, Petticrew M, et al. Preferred reporting items for systematic review and meta-analysis protocols (PRISMA-P) 2015 statement. Syst Rev 2015; 4: 1.

9. Atambay M, Karaman U, Daldal N, Colak C. [The prevalence of microsporidium among adult patients admitted to the parasitology laboratory at the Inonu University Turgut Ozal Medical Center]. Turkiye Parazitol Derg 2008; 32: 113-5.

10. Karaman U, Atambay M, Daldal N, Colak C. [The prevalence of Microsporidium among patients given a diagnosis of cancer]. Turkiye Parazitol Derg 2008; 32: 109-12.

11. Karaman U, Atambay M, Daldal N, Colak C. The Epidemiology of Microsporidias in Humans (Malatya sample). Turk J Med Sci 2009; 39: 281-8.

12. Calik S, Karaman U, Colak C. Prevalence of microsporidium and other intestinal parasites in children from Malatya, Turkey. Indian J Microbiol 2011; 51: 345-9.

13. Karaman U, Sener S, Calık S, Saşmaz S. [Investigation of microsporidia in patients with acute and chronic urticaria]. Mikrobiyol Bul 2011; 45: 168-73.

14. Türk S, Doğruman Al F, Karaman U, Kuştimur S. [Investigation of Microsporidia prevalence by different staining methods in cases of diarrhea]. Mikrobiyol Bul 2012; 46: 85-92.

15. Çetinkaya Ü, Hamamcı B, Kaynar L, Kuk S, Şahin İ, Yazar S. [Investigation of the presence of Encephalitozoon intestinalis and Enterocytozoon bieneusi in bone marrow transplant patients by IFA-MAbs method]. Mikrobiyol Bul 2015; 49: 432-8.

16. Hamamcı B, Çetinkaya Ü, Berk V, Kaynar L, Kuk S, Yazar S. [Prevalence of Encephalitozoon intestinalis and Enterocytozoon bieneusi in cancer patients under chemotherapy]. Mikrobiyol Bul 2015; 49: 105-13.

17. Özkoç S, Bayram Delibaş S, Akısü Ç. Evaluation of pulmonary microsporidiosis in iatrogenically immunosuppressed patients. Tuberk Toraks 2016; 64: 9-16.

18. Çetinkaya Ü, Yazar S, Kuk S, Sivcan E, Kaynar L, Arslan D, et al. The high prevalence of Encephalitozoon intestinalis in patients receiving chemotherapy and children with growth retardation and the validity of real-time PCR in its diagnosis. Turk J Med Sci 2016; 46: 1050-8.

19. Mumcuoglu I, Cetin F, Dogruman Al F, Oguz I, Aksu N. Prevalence of microsporidia in healthy individuals and immunocompetent patients with acute and chronic diarrhea. Infect Dis (Lond) 2016; 48: 133-7.

20. Oğuz Kaya İ, Doğruman AlF, Mumcuoğlu İ. [Investigation of Microsporidia prevalence with calcofluor white and uvitex $2 \mathrm{~B}$ chemiluminescence staining methods and molecular analysis of species in diarrheal patients]. Mikrobiyol Bul 2018; 52: 401-12.

21. Duzlu O, Yildirim A, Onder Z, Ciloglu A, Yetismis G, Inci A. Prevalence and Genotyping of Microsporidian Parasites in Dogs in Turkey: Zoonotic Concerns. J Eukaryot Microbiol 2019; 66: 771-7.

22. Pekmezci D, Pekmezci GZ, Yildirim A, Duzlu O, Inci A. Molecular detection of zoonotic microsporidia in domestic cats in Turkey: a preliminary study. Acta Parasitol 2019; 64: 13-8. 
23. Bilgin T, Usluğ S, Karademir GK, Okur M, Yetişmiş G, Yıldırım A. [Sağlıklı Sığırlarda Enterocytozoon bieneusi'nin Moleküler Prevalansı ve Filogenetik Karakterizasyonu]. Turkiye Parazitol Derg 2020; 44: 36-42.

24. Qiu L, Xia W, Li W, Ping J, Ding S, Liu H. The prevalence of microsporidia in China: a systematic review and meta-analysis. Sci Rep 2019; 9: 3174.

25. Mathis A, Weber R, Deplazes P. Zoonotic potential of the microsporidia. Clin Microbiol Rev 2005; 18: 423-45.
26. Wan Q, Lin Y, Mao Y, Yang Y, Li Q, Zhang S, et al. High prevalence and widespread distribution of zoonotic Enterocytozoon bieneusi genotypes in swine in Northeast China: implications for public health. J Eukaryot Microbiol 2016; 63: 162-70.

27. Ghoyounchi R, Ahmadpour E, Spotin A, Mahami-Oskouei M, Rezamand A, Aminisani N, et al. Microsporidiosis in Iran: a systematic review and meta-analysis. Asian Pac J Trop Med 2017; 10: 341-50. 